\title{
The Effect of Herbal Extracts and Probiotic Feeding On Productivity and Quality of Broilers
}

\section{Hasibuan Ahmad Syukur *, Silalahi Jansen, Masfria}

Department of Chemistry, Faculty of Pharmacy, Universities Sumatera Utara, Medan, Indonesia.

\begin{abstract}
A B S T R A C T
Objective: To find out the effect of probiotics, javanese turmeric (Curcuma xanthorrhiza) and breadfruit (Artocarpus altilis) leaves extract in feedon productivity and quality of broilers.

Design: The design of this study was experimental research. The viscous herbal extract from javanese turmeric and breadfruit leaves were prepared by maceration with 96\% ethanol and the probiotics used EM4 (Effective Microorganisms-4). This study used male chicks and divided into 5 groups: (1) negative control treatment (feed), (2) positive controls (feed+antibiotics), (3) feed $+0.1 \%$ extract $+1 \%$ probiotics, (4) feed $+0.2 \%$ extract $+2 \%$ probiotics and (5) feed $+0.3 \%$ extract $+3 \%$ probiotics. The positive control used erythromycin. Feed intake, body weight gain and feed conversion rate were observed for 35 days. Total cholesterol and crude protein levels were examined on day 35 .

Interventions: The intervened variable was the concentration of extract used.

Main outcome measures: The main measurement in this study were feed conversion rate,total cholesterol and crude protein levels.

Results: The results showedthat combination of probiotics, javanese turmeric and breadfruit leaves herbal extract increased body weight $10.71 \%$ and feed intake $61.60 \%$, decreased feed conversion $13.97 \%$ and total cholesterol $27.95 \%$ of treatment group and significantly different with negative and positive control groups $(\mathrm{p}<0.05)$ but did not affect $(\mathrm{p}>0.05)$ to crude protein levelsof treatment group or negative and positive control group.

Conclusion: The administration of probiotics, javanese turmeric and breadfruit leaves herbal extract increased productivity and decreased cholesterol levels but did not affect crude protein levels in broilers.
\end{abstract}

Keywords: Javanese turmeric, Breadfruit leaves, Probiotics, Broilers, Productivity, Quality.

A R T I C L E I N F 0: $\quad$ Received 28 April 2019; $\quad$ Review Completed 25 May 2019; Accepted 28 May $2019 ; \quad$ Available online 15 June 2019

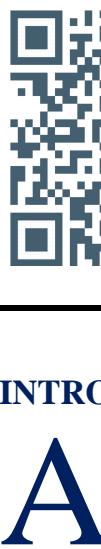

Cite this article as:

Hasibuan Ahmad Syukur*, Silalahi Jansen, Masfria, The Effect of Herbal Extracts And Probiotic Feeding on Productivity And Quality of Broilers, Asian Journal of Pharmaceutical Research and Development. 2019; 7(3):05-09 DOI: http://dx.doi.org/10.22270/ajprd.v7i3.521

*Address for Correspondence:

Ahmad Syukur Hasibuan, Department of Chemistry, Faculty of Pharmacy, Universities Sumatera Utara, Medan, Indonesia

\section{INTRODUCTION}

$\mathrm{A}$ ntimicrobial compounds are commonly included in poultry feeds for growth promotion and diseases prevention ${ }^{1}$. Because of the antibiotic resistance and the implications on human health, there is a need to find out safe alternatives to replace antibiotic as a growth promoters in the poultry industry ${ }^{2}$. Feeds containing no chemical additives are increasingly used in poultry nutrition. In many countries, efforts are being made to ban all types of antibiotic growth promoters. For this reason, herbs and natural feed additives are being investigated as natural sources biologically important substances. Gou et al. ${ }^{3}$ have demonstrated that herbs and herbal products have a positive effect on broiler growth performance.

Breadfruit leaves (Artocarpus altilis) is widely used by Indonesian society as a traditional medicine, because flavonoids, antocyanin, hydrocyanic acid, acetylcholine, tannin, riboflavin, saponin, phenol, quercetin, champerol,
B-carotene, vitamin $\mathrm{C}$ and potassium are efficacious for treatment and functioning as antioxidant. Supplementation of breadfruit leaves powder in feed decreases abdominal fat, intramuscular meat fat and meat cholesterol content ${ }^{4,5}$.

Curcuma xanthorrhiza (commonly known as javanese turmeric or temulawak in Indonesia), grows in SouthEast Asia and found both wild and cultivated in Indonesia. It is traditionally used for medicinal purposes. The rhizome and root of this plant contain beneficial constituents that have been used in the treatment of acne and skin inflammations. More recently, studies have demonstrated that products derived from $C$. xanthorrhiza showed antioxidative, detoxifying and anticarcinogenic characteristics ${ }^{6}$.The addition of probiotics feeds benefit the host animal by stimulating appetite ${ }^{7}$, improve intestinal microbial balance ${ }^{8}$, stimulate the immune system ${ }^{9}$, decrease $\mathrm{pH}$ and release bacteriocins ${ }^{10}$ that 


\section{Treatments}

compete with other microbes for adhesive site, improve egg mass, egg weight, egg size in layers ${ }^{7,11}$ and feed intake in layers and also depress serum and egg yolk cholesterol concentrations in hens ${ }^{12,13}$. The aim of this study was toinvestigate the effect of javanese turmeric, breadfruit leaves extract and probiotics on broiler productivity and quality to replace antibiotic as a growth promoters in the poultry industry.

\section{MATERIALS AND METHODS}

\section{Preparation of herbal extracts}

Javanese turmeric rhizomes were obtained from traditional markets Jamin Ginting street, Padang Bulan district, Medan regency, Sumatera Utara province, Indonesia. Breadfruit leaves were obtained from the Indonesian Medicinal Plant Garden (TOI), Faculty of Pharmacy University of Sumatera Utara, Medan. The plants were identified at Herbarium Medanese Laboratory. Javanese turmeric (1000 g) and breadfruit leaves extracts $(1000 \mathrm{~g})$ extracts were prepared using maceration method with $20 \mathrm{~L} 96 \%$ ethanol. Then the filtrate was evaporated in a rotary vacuum evaporator and made viscous by heating in a water bath.. The yield of ethanol extract of javanese turmeric was $195 \mathrm{~g}$ (19.5\%) and breadfruit leaf was $115 \mathrm{~g}(11.5 \%)$. The yield of ethanol extract of javanese turmeric was $195 \mathrm{~g}$ (19.5\%) and breadfruit leaves was $115 \mathrm{~g}(11.5 \%)$.

\section{Material, chemical reagents and tools}

The ingredients used in this study were breadfruit leaves (Artocarpus altilis), javanese turmeric (Curcuma zanthorrhiza), ethanol $96 \%$, Effective Microorganisms-4 (EM4) (PT. Songgolangit Persada) as probiotics, erythromycin as antibiotic, Bestaquam (Bestar) as desinfectan, Cosumix Plus 750 (Novartis), Biogreen (Laboratoires Biove), Neo Meditril (Medion), Linco Spectin (Zoetis Suzhou), ND vaccine, Gumboro vaccine, $\mathrm{NaOH}, \mathrm{H}_{2} \mathrm{SO}_{4}, \mathrm{CuSO}_{4}, \mathrm{~K}_{2} \mathrm{SO}_{4}$ and mengsel indicator.

\section{Experimental procedures}

Chicks were placed into 4 cages per plot. Chicks were fed and drink according to the type of treatment, then chicks were weight as the initial body weight. The next day until the $35^{\text {th }}$ day the feed was replaced every day according to the type of treatment. Broilers were weighed to determine weight gain once a week, leftover food was weighed every day to find out how much food were consumed.

Table 1: Effect of herbs and probiotics on broiler for 5 weeks

\begin{tabular}{|l|l|l|l|l|l|}
\hline \multirow{3}{*}{ Group } & \multicolumn{3}{|l|}{ Productivity parameter } & Quality parameter \\
\cline { 2 - 6 } & Body weight (g) & Feed intake (g) & FCR & Total cholesterol (mg/dl) & Protein (\%) \\
\hline Co & $1866.13 \pm 26.0445$ & $214.53 \pm 18.3$ & $1.72 \pm 0.06$ & $164.67 \pm 2.517$ & $\mathbf{2 0 . 2 9} \pm \mathbf{0 . 1 0}$ \\
\hline C+ & $1980.54 \pm 75.3769^{\mathrm{a}}$ & $437.5 \pm 60.4^{\mathrm{a}}$ & $1.38 \pm 0.11^{\mathrm{a}}$ & $162.67 \pm 2.517$ & $\mathbf{2 0 . 4 3} \pm \mathbf{0 . 3 4}^{\mathrm{b}}$ \\
\hline T1 & $1977.99 \pm 42.4860^{\mathrm{a}}$ & $474.64 \pm 136.7^{\mathrm{a}}$ & $1.42 \pm 0.05^{\mathrm{a}}$ & $155.67 \pm 5.686^{\mathrm{a}}$ & $\mathbf{2 0 . 4 5} \pm \mathbf{0 . 1 6}^{\mathrm{b}}$ \\
\hline T2 & $1996.61 \pm 26.0371^{\mathrm{a}}$ & $646.06 \pm 21.17^{\mathrm{a}}$ & $1.46 \pm 0.04^{\mathrm{a}}$ & $142.67 \pm 17.09^{\mathrm{a}}$ & $\mathbf{2 0 . 6} \pm \mathbf{0 . 4 3}^{\mathrm{b}}$ \\
\hline T3 & $2090.46 \pm 26.6087^{\mathrm{a}}$ & $849.23 \pm 109.1^{\mathrm{a}}$ & $1.36 \pm 0.04^{\mathrm{a}}$ & $128.67 \pm 4.163^{\mathrm{a}}$ & $20.29 \pm 0.10^{\mathrm{b}}$ \\
\hline
\end{tabular}

Note: Note: FCR: Food Convertion Rate; $\mathrm{Co}=\mathrm{Negative}$ control (feed); $\mathrm{C}+=$ Positive control (feed+antibiotic); $\mathrm{T} 1=\mathrm{Feed}+0.1 \%$ extract $+1 \%$ probiotics; $\mathrm{T} 2=$ Feed $+0.2 \%$ extract $+2 \%$ probiotics; $\mathrm{T} 3=$ Feed $+0.3 \%$ extract $+3 \%$ probiotics

${ }^{a}$ Significant difference with negative control $(\mathrm{p}<0.05)$

${ }^{\mathrm{b}}$ Not significant difference with negative control $(\mathrm{p} \geq 0.05)$ 


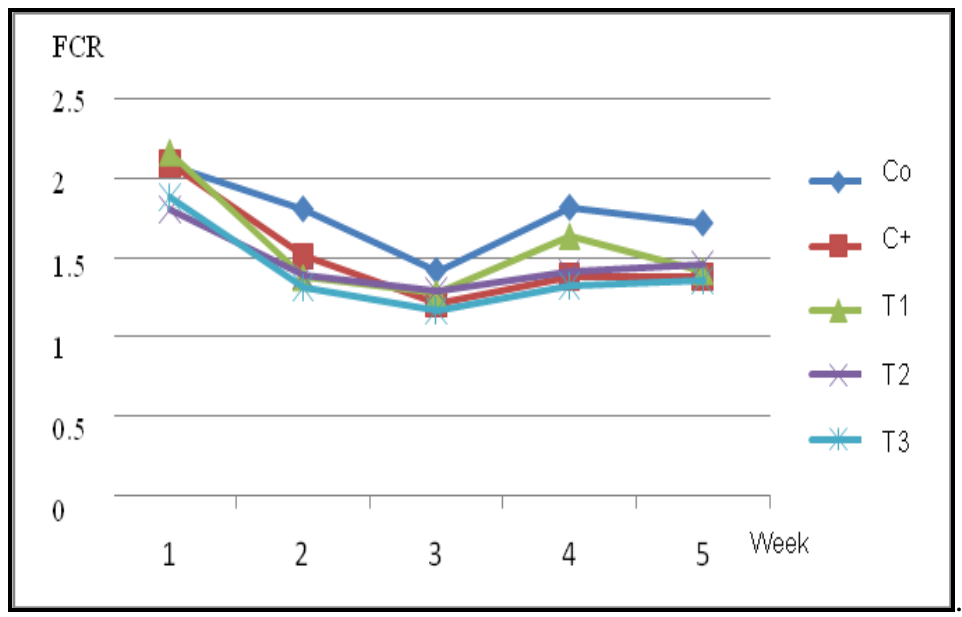

Figure 1: Effect of herbs and probiotics on broiler feed conversion rate for 5 weeks $(\mathrm{g} / \mathrm{head} / \mathrm{week})$

Note: FCR: Food Convertion Rate; $\mathrm{Co}=$ Negative control (feed) $\mathrm{C}+=$ Positive control (feed + antibiotic); $\mathrm{T} 1=\mathrm{Feed}+0.1 \%$ extract $+1 \%$ probiotics; $\mathrm{T} 2=$ Feed $+0.2 \%$ extract $+2 \%$ probiotics $; \mathrm{T} 3=$ Feed $+0.3 \%$ extract $+3 \%$ probiotics

The Effect of herbs and probiotics on broilers body weight

Based on observations, it was shown Table 1. that chicks treated as controls showed weight gain from the first week to the last week of the experiment. Statistical analysis showed a very significant difference between the control and treatment $(\mathrm{p}<0.05)$. Combination of herbal extracts and $3 \%$ probiotics increased body weight $10.71 \%$ higher than the negativeand positive control group.

The results of the study were supported by the results of the study of Astuti ${ }^{16}$ which showed that the highest concentration of liquid probiotics added to feed increased weight gain and had a very significant effect $(\mathrm{p}<0.05)$ on broiler body weight.

Whereas Sinurat et.,al ${ }^{17}$ reported that the administration of javanese turmeric flour in broiler rations did not have a significant effect on broiler weight gain. Differences in the results of research on the use of bioactive plants in rations are often reported. One possible cause is the difference in the content of the active ingredients contained in the material used ${ }^{17}$.

Increased of feed intake was strongly associated with increased body weight. So that in this case, combination of probiotics, javanese turmeric, and breadfruit leaves herbal extract showed the highest increase (61.60\%) then positive and negative control group, presumably because of the effect of the content of each herbal extract on treatment.

\section{The Effect of herbs and probiotics on feed intake}

As can be seen from Table 1, the T3 group showed increase in feed intake from the first week to the fifth week (34.6 $\mathrm{g}$ to $136.43 \mathrm{~g}$ ), lower than positive and negative control group but had highest increase in body weight parameter. This is in Accordance with the study by Haddanin et al. ${ }^{18}$ that using probiotics in the feed of laying hens on egg production. Feed intake at the level of probiotics is lower than feed without probiotics Astuti ${ }^{16}$ reported that the higher the concentration of probiotics given, the higher the bacteria contained in it, the livestock will be more efficient in consuming feed. This could be due to the more probiotics given, the more feed contain Bacillus sp. the more villi on the intestinal surface. The more villi in the intestine, the better digestion in chickens so that they consume less feed ${ }^{19}$.

The effect of herbs and probiotics on Feed Conversion Ratio (FCR)

As can be seen in Table 1. all group of treatments given the lowest of FCR found in group T3, this result was also supported by statistical analysis where there was a very significant difference between the control and treatment of extract $(\mathrm{p}<0.05)$.

On the other hand Yasni et al. ${ }^{20}$, also reported that curcuma extract can reduce ration consumption in mice made with diabetes. However, based on Tugiyanti ${ }^{5}$, supplementation from breadfruit leaves powder did not significantly affect feed conversion in 9-week-old Tegal duck. FCR in meat is strongly related to feed efficiency or conversion of feed into meat.

The Effect of herbs and probiotics on crude protein and cholesterol

In all treatment groups given a combination of herbal extracts and probiotics, crude protein levels were almost the same in all control and treatments, the lowest cholesterol levels found in T3 group (combination of herbal extracts and probiotics with highest concentration) were $128.67 \mathrm{mg} / \mathrm{dl}$, decreased $27.95 \%$. Based on statistical tests, it was found, there were significant differences in the negative control cholesterol level, positive control and T1, T2 and T3 groups $(\mathrm{p}<0.05)$ as can be seen on Fig. 2 . 


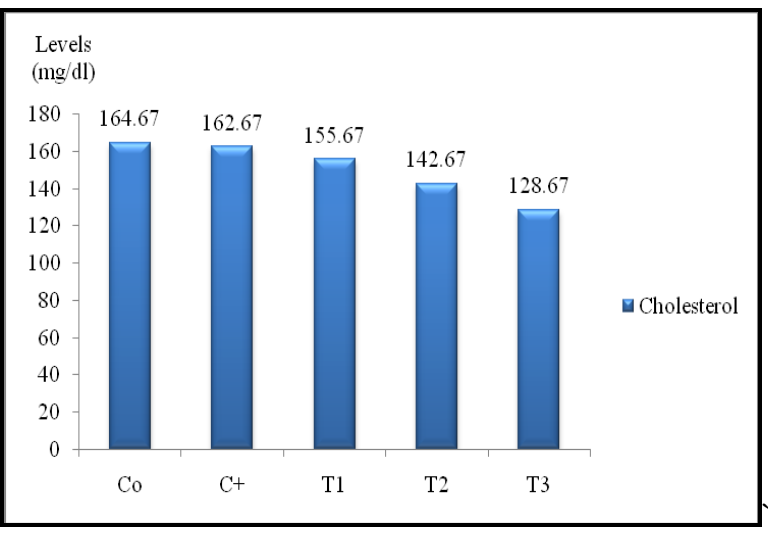

Figure 2: The Effect of herbs and probiotic on broiler total cholesterol for 5 weeks

Note: $\mathrm{Co}=$ Negative control (feed); $\mathrm{C}+=$ Positive control $($ feed+antibiotic $) ; \mathrm{T} 1=$ Feed $+0.1 \%$ extract $+1 \%$ probiotics; $\mathrm{T} 2=$ Feed $+0.2 \%$ extract $+2 \%$ probiotics; $\mathrm{T} 3=$ Feed $+0.3 \%$ extract $+3 \%$ probiotics.

Combination of probiotics, javanese turmeric extract and breadfruit leaves affect the production and increased bile secretion leading to greater cholesterol metabolism, cholesterol will come out with feces resulting in decreased blood cholesterol. Javanese turmeric can metabolize body fat and can reduce cholesterol levels resulted in hypocholesterolemia. Curcuminoid in javanese turmeric has activity increasing bile production and secretion, stimulates the release of pancreatic enzymes which can increase the metabolism of carbohydrate, protein, and fat ingredients so that the digestion process is fast and optimal. Probiotic bacteria can reduce cholesterol levels, this ability comes from anti-cholesterol substances produced by bacteria that inhibit the work of cholesterolforming enzymes, cholesterol reduction also occurs because during the growth of bacteria absorb a certain amount of cholesterol into the cells ${ }^{17}$.

Probiotics can degrade cholesterol into coprostanol which cannot be absorbed by the intestine and then excreted along with feces so that the cholesterol absorbed by the body becomes low. In line with the hypothesized by Ignatova et al. ${ }^{21}$ that supplementation of probiotics can reduce serum triglycerides and cholesterol in poultry. The administration of Streptococcus thermophillus lactic acid bacteria has reduced broiler blood cholesterol levels ${ }^{16}$.

Breadfruit leaves contain flavonoids, vitamin $\mathrm{C}$ and carotene which can function as antioxidants. This antioxidant, in addition to inhibiting the oxidation process can inhibit the activity of HMG-CoA reductase enzyme in the process of cholesterol synthesis. Inhibition of the activity of this enzyme causes the absence of mevalonate

\section{REFERENCES}

1. Shane SM, Mannanoligosaccharides in poultry nutrition: mechanisms and benefits. Proceedings of Alltech's 17th Annual Symposium. 2001; p. 65-77.

2. Owens B, Tucker LC, Collins MA, \& McCracken KJ. Effects of different feed additives alone or in combination on broiler performance, gut microflora and ileal histology. British poultry science. 2008; 49(2):202-212.

3. Gou F, Kwakkel RP \& Verstegen MWA, The use of Chinese herbs as alternative for growth promoters in broiler diets. Proceedings of XXI World's Poultry Congress, August. 2000; p. 20- 25.

4. Tugiyanti E, \& Susanti E, The Effect of Breadfruit Leaves Flour (Artocarpus altilis) on Number of Blood Cells And Correlation from HMG-CoA; mevalonate will be converted to squall, lanosterol, dihydrolanosterol, D 8-dimethylsterol, 7dihydroololesterol and finally cholesterol. Besides that, Flavonoids also have a positive effect on decreasing serum total cholesterol levels through increasing bile acid excretion with impurities 5 .

The administration of probiotic, javanese turmeric and breadfruit leaves extract had no significant effect ( $p>$ 0.05 ) on the percentage of crude protein. According to the study of Tugiyanti et, al. ${ }^{4}$, that breadfruit flour does not increase the protein content of duck meat, because the content of anti-nutrients in breadfruit leaves flour such as tannins, saponins and crude fiber inhibits the digestive process, so it also reduced the process of absorption of protein in the small intestine.

Supplementation of breadfruit leaves flour into feed has no significant effect on the levels of male chicken broiler meat protein because the antioxidant content in breadfruit leaves is able to maintain meat protein levels because antioxidants that have many $\mathrm{OH}$ groups that scavenge free radicals. The more active antioxidants contained in the feed, the more they can maintain their protein levels ${ }^{4}$.

The administration of probiotic, javanese turmeric and breadfruit leaves extract had no significant effect ( $p>$ 0.05 ) on the percentage of crude protein. According to the study of Tugiyanti et, al. ${ }^{4}$, that breadfruit flour can not increase the protein content of duck meat, because the content of anti-nutrients in breadfruit leaves flour such as tannins, saponins and crude fiber inhibits the digestive process, so it also reduced the process of absorption of protein in the small intestine.

Supplementation of breadfruit leaves flour into feed has no significant effect on the levels of male chicken broiler crude protein because the antioxidant content in breadfruit leaves is able to maintain meat protein levels because antioxidants that have many $\mathrm{OH}$ groups that scavenge free radicals. The more active antioxidants contained in the feed, the more they can maintain their protein levels ${ }^{4}$.

\section{CONCLUSION}

Based on the results of the study it can be concluded that the administration of curcuma herbal extract, breadfruit leaves extract and probiotic increased the productivity and decreased cholesterol levels but did not affect crude protein levels of broilers.

\section{CONFLICT OF INTERESTS}

All authors have no to declare

Between Cholesterol Blood and Meat of Tegal Ducks 10 Weeks Age. Animal Production. 2017; 19(3):179-188.

5. Tugiyanti E, Vitamin E ( $\alpha$-Tocopherol) and Vitamin C (Ascorbic Acid) Supplementation on Cholesterol and Triglyceride Blood Profile of Male Native Muscovy. In Proceedings of International Seminar on Livestock Production and Veterinary Technology. 2016; 370-377.

6. Rukayadi Y, Yong D, Hang JK, In vitro anticandidal activity of Xanthorrhizol isolated from Curcuma xanthorrhiza roxb. Journal of Antimicrobial Chemotherapy. 2006; 5(7):1231-1234.

7. Nahashon, Samuel N, Nakaue, Harry S; Mirosh, Larry W. Nutrient retention and production parameters of Single Comb White Leghorn layers fed diets with varying crude protein levels and supplemented with direct-fed microbials. Animal feed science and technology.1996; 61(1-4):17-26. 
8. Fuller, R, Probiotics in man and animals A Review. Appl Bacteriol. 1989; 66(5):365-378.

9. Toms C, Powrie, Fiona. Control of intestinal inflammation by regulatory T cells. Microbes and infection. 2001; 3 (11):929-935.

10. Rolfe RD, The role of probiotic cultures in the control of gastrointestinal health. J. Nutr. 2000; 130(2):396S-402S

11. Jin LZ, YW. Ho N. Abdullah and Jalaludin S. Probiotics in poultry: modes of action. World's Poult. Sci. J., 1997; 53(4):351-368.

12. Mohan B, Kadirvel, R, Bhaskaran M, \& Natarajan A. Effect of probiotic supplementation on serum/yolk cholesterol and on egg shell liquidness in layers. British Poultry Science. 1995; 36(5):799803.

13. Kurtoglu VF. Kurtoglu E, Sker B, Coskun T. Balevi and ES Polat. Effect of probiotic supplementation on laying hen diets on yield performance and serum and egg yolk cholesterol. Food Addit. Contam. 2004; 21(9):817-23.

14. Mukherjee K L. Medical Laboratory Technology, Tata McGraw-Hill Education. 2013; 3(3):234.

15. Chromý V, Vinklárková B, Šprongl L, \& Bittová M, The Kjeldahl method as a primary reference procedure for total protein in certified reference materials used in clinical chemistry. I. A review of Kjeldahl methods adopted by laboratory medicine. Critical reviews in analytical chemistry. 2015; 45(2):106-111.
16. Astuti FK, Busono W, \& Sjofjan O. Effect of liquid probiotics in feed on the appearance of production in broilers. Indonesian Journal of Environment and Sustainable Development. 2015; 6 (2):87-91.

17. Sinurat AP, Purwadaria T, Bintang IAK, Ketaren PP, Bermawie N, Raharjo M, \& Rizal M. The utilization of turmeric and curcuma xanthorrhiza as feed additive for broilers. Jurnal Ilmu Ternak dan Veteriner. 2009; 14(2):90-96.

18. Haddanin MSY, Abdulrahim SM, Hashlamoun EAR and Robinson RK. The Effect of Lactobacillus Acidophilus On the Production and Chemical Composition of Hen Eggs. Poultry Science. 1996; 75(4):491-494.

19. Sellars, R.I. Acidophilus products. In: Therapeutic Properties of Fermented Milks. Robinson (Ed.) Chapman \& Hall. London, New York, Tokyo, Melbourne, Madras.1991; p. 1123.

20. Yasni S, Katsumi I And Michihiro S. Effects of An IndonesianMedicinal Plant, Curcuma xanthorrhiza Roxb.On The Levels of Serum Glucose, And Triglyceride, Fatty Acid Desaturation, And Bile AcidExcretion In Streptozotocin-Induced Diabetic Rats. Agriculture. Biology. Chem. 1991; 55(12):30053010 .

21. Ignatova M, SredkovaV, V Marasheva. Effect of Dietary Inclusion of Probiotic on Chickens Performance and Some blood Indices. Biotechnology in Animal Husbandry. Institute for Animal Husbandry. 2009; 25(56):1079-1085. 